\title{
The System of Land Ownership and Its Effect on Agricultural Production: The Case of Ghana
}

\author{
Inez Naaki Vanderpuye ${ }^{1}$, Samuel Antwi Darkwah ${ }^{1} \&$ Iva Živělová ${ }^{1}$ \\ ${ }^{1}$ Mendel University, Brno, Czech Republic \\ Correspondence: Inez Naaki Vanderpuye, Mendel University, Brno, Czech Republic. E-mail: \\ xvanderp@mendelu.cz
}

Received: January 12, 2020

Accepted: March 3, $2020 \quad$ Online Published: April 15, 2020

doi:10.5539/jas.v12n5p57

URL: https://doi.org/10.5539/jas.v12n5p57

\begin{abstract}
Most African continents have pressing issues on individual rights to property and natural resources, given the relatively poor economic conditions and the belief of personal ownership to a property right (Joireman, 2008). Ghana, like many African countries like Mozambique and Uganda, have laws to the right of property that is the traditional system of land rights. Most of the African countries depend on the large share of natural capital from the natural resources for the economic growth of the country. Some emerging economies can have sustained economic growth due to their reliance on natural resources such as oil and gas. This paper investigates property rights, land ownership, and land inheritance and their effect on agricultural production in Ghana. To undertake this research, a sample of 35 respondents were analysed using the SPSS software. The analysis was based on characteristics such as gender, age, and educational level of the respondents. The research results indicate that men inherit more than women, and family ownership is the most popular type of land inheritance in Ghana. Also, people with a lower level of education are likely to inherit the land and own land. Finally, the patrilineal system is the most popular system of inheritance in Ghana.
\end{abstract}

Keywords: agriculture, Ghana, inheritance, land, natural resources, ownership

\section{Introduction}

There has been a debate about the conception gathered on the property rights and its rules that have been set in a country by politicians or political economist (Schelager \& Ostrom, 1992; May, 2015). This has created resource degradation and environmental problems in most countries, mainly the developing world. In the developing world, including Ghana, the welfare of the individual, households, and communities mostly depend on natural resources, be it renewable or non-renewable. Thus, property rights to resources are significantly essential in governing natural resources. Furthermore, the welfare of the individual or household depends immensely on renewable resources; therefore, property rights to resources play a fundamental role in regulating the patterns of natural resource management. Policies set by the government that shape property rights contribute to significant roles in promoting the country's economic growth, equity of distribution, and the sustainability of the resource base (Meinzen-Dick, Brown, Feldstein, \& Quisumbing, 1997; May, 2015). The progress of property rights on natural resources in the world has a significant advantage in both the household income and economic investment. Therefore, the role of the state regarding property rights helps formulate laws in codifying and protecting such rights as well as to provide the preconditions for economic growth.

Natural resources can be identified as the type of resources found and used that comes from the natural environment. These natural resources can be distinguished by its natural state or man-made state. Most of the resources found in the natural environment cannot be identified as man-made resources. Therefore, it can be argued that property rights immensely influence control of resources (land and natural). There have been questions raised on the issue of property rights regarding who has the rights to what resources such as land, who has access to these resources and who has responsibilities for the management of these resources. Property rights on land such as agricultural lands, forest resources, freshwater, and coastal resources, wild species of plants or animals or watersheds create incentives and disincentives for sustainable management and governance of natural resources.

There have been questions raised about property rights and its importance on natural resources (USAID, 2006). These help the markets focus its concerns on timber or non-timber forest product, agricultural products, payment 
for environmental services and other revenue-generating activities. Becker (2014) examines the overall reasons concerning the systems of private property rights and discusses the main arguments that influence the rights and responsibilities of property ownership. Based on this argument, natural resources derived occupancy, labor, utility, liberty, and virtue with the standard anti-property and the belief and process that distribution must take precedence over private ownership.

As indicated by Heltberg (2002), developing countries depend mostly on several important ways in their natural capital. Peasants, fishermen, and cattle in Africa and other developing countries earn their living directly from the utilization of natural resources such as farmlands, water, air, forest, grazing areas, plants, and animals. In most of these countries, the resources are increasingly exposed to unsustainable exploitation, pollution and conversion to other uses. When natural resources degrade or perish, the livelihoods of the people disappear that aggravate problems of rural property, food insecurity, and rural-urban migration.

\subsection{Land Ownership Right}

Property rights can be described as an area where an individual or group can own and control the resource and by giving them the ability to exclude others from using or encroaching on the resources. In general, land disputes can be seen as typical, where two parties may have conflicts over the rights to land. In today's economy, property ownership, or the rights to use and the transfer of ownership can be created based on the contact that can be described as property rights (Amacher \& Malik, 1996). Property rights can be understood as a web of interest that aids different parties with the legal rights that can be based on customary or local norms and state laws within a country Meinzen-Dick and Mwangi (2008). This helps manage and regulates these rights to property and natural resources, either renewable or non-renewable resources. Moreover, property rights allow owners to make informed decisions on the use of their properties, for instance, on economic activities. The property right is defined as ownership to use, to exclude others from taking control and the right to transfer ownership to another, for example, land (Becker, 2014). The rights of property are legally assigned to the individual and are entitled to the rights of the property. As examined by Alchian (1989), property right is a socially enforced right to the owner and select the use of economic goods thus legally assigned to an individual and is entitled with the rights over the assets. Property rights entail the relationship between people or groups (Bromley, 1991). This, however, includes more than just a title or a piece of paper specifying the ownership of a property like land or other resources.

The right to property incorporates a diverse set of tenure rules and other aspects to the use and ownership of resources. Property rights describe the legal ownership of resources and how they are used. These resources are either renewable or non-renewable and can be owned by individuals, associations, or government. In many countries, individuals exercise their rights to property, either holding, renting or to sell the property. It is believed that an individual capacity to own and manage a property describes its right to the property and the relationship between people or groups. This involves more than a title deed or a piece of paper to a property that specifies the ownership of the property like land or other resources. Merrill and Smith (2001) stated that some economic scholars consider and argue that property rights can be described as the ownership rights that are generated and controlled over the property and resources (Becker, 2014). The rights of these properties thus need to be fixed and the need to portray the relationships among the parties. However, some forms of property rights include:

$>$ The common property where there is a collective property that is owned, managed and controlled by the joint owner, such as groups or associations of individuals. Due to the joint ownership form of this property, individuals can overcome and manage conflicts through the shared benefit and enforcement of responsibilities.

$>$ Public property can also be referred to as the state property that is typically owned, managed, and controlled by the government of the country.

Individual or private property describes the rights of an individual's access, use, and management of the property.

Property rights have both implicit and explicit means of managing and regulating the environment. Specifically, the laws of property rights put specific restrictions that enable an organized environment to help to manage land disputes. This serves as an explicit impact of property and ownership rights on an organized environment. Also, there is an implicit impact of property right laws on the environment, such as a good property and ownership right laws enables good governance that helps improve the environment. The laws placed on the transfer of property rights helps to prevent and resolve any environmental threats in a country. The most valuable property could be land, buildings, etc. Land can be described in Ghana as the survival of the fittest, where whoever has 
enough capital and influence can take the land that may belong to another individual. This can be said to be land grabbing that leads to poverty (Kugbega, 2018).

\subsection{Inheritance}

This can be described as the transfer of assets such as properties, titles, and rights from one person to another. The capabilities and limitations for the enactment of the property rights in Africa to recognize overlapping interests can be considered to preserve environmental functions and thus help protect the livelihood of the poor (Ikdahl, Hellum, Kaarhus, Benjaminsen, \& Kameri-Mbote, 2005). This has been resurfaced with the development policies in land tenure systems, such as changes in the rules governing the access, use, transfer, and validation of land and natural resources. Inheritance consists of the following: Customary land ownership, individual or private ownership, State ownership (Blocher, 2006).

\subsubsection{Customary Land Ownership System}

In Africa, customary land ownership system legally recognizes the existing rights that are subject to minimum conditions (Deininger 2003). Customary land ownership is more effective with the legal recognition of members and owners of the land that greatly ensures less conflict and enhances occupants' security. Based on this ideology of customary land systems, the demarcations of the land boundaries in these countries enable communities to avoid outsiders encroaching on their properties. This ensures that the authorities of the community set up a well-defined rule of assigning land within a community and help manage the rights on the property for the people in the community. A country like Ghana has almost 80 percent of the land under the customary tenure system (Kasanga \& Kotey, 2001). Most countries have laws that are legally binding as to regards to property ownership. In addition, properties can be acquired and owned by individuals or associations through leasing, sale, or inheritance. A notable example is in Africa, particularly Ghana, whereby properties and resources are owned by individuals through inheritance. The traditional land tenure system in Ghana indicates how the customary authority, like the tribal chiefs, have claim and control over the rights of property in the region and grant claims and regulates in any form of a land transfer (Lastarria-Cornhiel, 1997; Peters, 2013).

These forms of laws of the rights to property by the customary chiefs are granted on a long-term agreement basis or transfer of ownership. However, due to the increasing population in Africa, the rights on land and other resources have become intense for individual ownership of land as such emphasizing the individualistic rights, granting the ability to transfer the property without needing a community sanction. The land rights and laws in Ghana typically follow a particular ideal form of the communal land tenure system that governs the individualistic right to property (Kasanga \& Kotey, 2001). An example sighted by Bruce (1988) relates to the property rights on land being recognized by the court to be existing "family land" where the rights and control of these lands are owned by the larger kinship groups in the society. This system of land ownership is operated by a household head; thus, the rights and regulations imposed on the sale or lease of land by the household to the individuals that lease the properties may not have the ability to exercise their rights (de facto). Indigenous tenure systems pose a degree of insecurity, for example, by destroying incentives to plant tree crops. This is evident when property owners with temporal or fragile titles have succeeded in planting a tree to enhance their tenure systems.

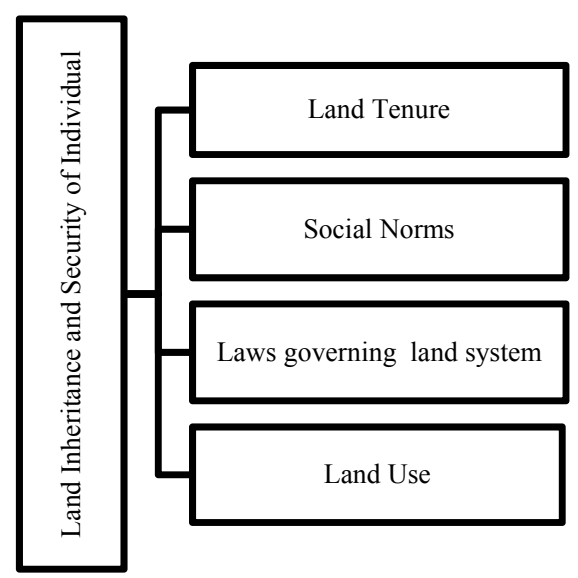

Source: Author, 2019. 


\subsubsection{Individual or Private Ownership}

Deininger (2003) explains this form of ownership as considered formal ownership of land titles in Africa, particularly in the case of Ghana. There is an inefficient land administration in countries like Ghana that does not ensure a secure form of land demarcations of the land boundaries in the communities. There is a lack of transparency as to who owns such kind of land. A situation as this requires an institution with sufficient government conditions that can be a precondition for the state to deliver a valid property right for the landowners accurately.

\subsubsection{State Ownership}

There is a significant investment opportunity of the state land system and helps occupants make essential decisions and efforts to increase their level of security and, at the same time, are vulnerable to evict threats. Deininger (2003), observes how this kind of system has limited land rights; as such, the occupant is not able to make full use of the land. The legal rights placed on these lands to regularise the importance of their possessions of the property, and institutions can lease the land for a long-term to both lenders and borrowers. This allows land to be transferred to different occupants.

\subsubsection{Land Tenure System in Ghana}

Land tenure can be defined as the process that an individual or group of people hold concerning land and other land-based resources such as minerals and trees. This aims at analysing the social, political, and customary relationship of land inheritance in Ghana. The tenure system in Ghana focuses on the land ownership distribution and the rights imposed on land use in the country (Ubink \& Quan, 2008). Property rights do not only look at the relationship but also focuses on the structure that governs the access to natural resources, which provides the opportunities and reward patterns in land use. The tenure system can regulate the individual's security that influences social stability and the individual income and expenditure patterns of land use. In conclusion, property rights provide individuals with security, confidence, and social support. Land and natural resources control and ownership in Ghana are a bit complicated with the kind of tenure systems whereby the stool controls land within a community, the rights of the properties, on the other hand, can belong to different people.

In Ghana, there are two types of the land tenure system that are typically described as the customary and statutory land tenure system. The customary land system looks at the norms, customs, and traditions on the land rights within a society (Yeboah \& Shaw, 2013). This kind of tenure system has been in existence since the colonial days with enacted laws and its judiciary precedents. Dadson (2006), describes this kind of law as explicit with rules founding its legitimacy from the traditions and custom norms in the society as a result of the linkage of the local cultural practices. The statutory land tenure system, on the other hand, is a legislative enactment of government policies that include the land registration system and the land-use planning system (Agbosu, 2000).

\subsubsection{Land Rights Management}

There have been several laws such as the mineral policies and taxation codes put in place to regulate the mining sector in sub-Saharan Africa from the beginning of the political atmosphere that brought about an increase in the participation of the mining mineral resources (Hilson \& Yakovleva, 2007). Property rights to land and natural resources consist of total control and management over that resource. This is the ability to use the resources, which is the most valuable and that being the most important form of property control for an individual with the ownership title on the resources.

Nyame and Blocher (2010), explained that from the norm of post-colonial Africa, there had been stated participation of commercial enterprises, which includes mining seen both in national and civil leadership from the beginning were laws were promulgated through a decree by the military regimes. Nyame and Blocher (2010) further examines the primary government objective during the post-colonial days was the seizure of minerals or the lands which brought little or no input to the landowners and stakeholders. The successful elected government amended to accommodate individual and customary land ownership that resulted in the formal state system. This form of the system has been the most accessible and familiar mechanism of land tenure for many miners and landowners, especially in Africa.

Ghana has been recognized for long as one of the richest mining countries in Africa. Hence, the colonial name derived from the mining possibilities as Gold Coast. Nyame and Blocher (2010) indicated the rights of individual landowners who could generally claim a portion of the land and the minerals mined on the land before and during the colonial era, which varied according to the relevant customary rules. For instance, the paramount chiefs of the Akan areas in Ghana were entitled to gold mined in the community. Due to the diverse tribe and 
ethical groups in Ghana, there was no uniformity in the customary law regarding the extraction of minerals in the country. Based on the current mining system, most mine developers may negotiate with traditional rulers in the acquisition of the minerals mined in the community, unlike in the past where there were no clear boundaries that distinguished land (Quisumbing, 2001). The demand for land placed on mines has led to conflict among family or community over ownership of land, which is a major source of livelihoods of many rural communities and mostly poor people in the community (Hilson, 2002).

\subsubsection{Effects of Land Ownership on Natural Resources}

Deininger (2003) indicates owning a property in the developing world can be a crucial advantage economic activity of an individual. More than 80 percent of land in Ghana is not registered and mostly belongs to family members with no clear title deeds of ownership. Therefore, this affects the individuals in need of land for agriculture purposes (Deininger, 2003). This form of land ownership and inheritance system in Ghana deprives the people of owning the land with the women most affected due to the bargaining power within the family (Lambrecht, 2016). Deere, Oduro, Swaminathan, and Doss (2013) emphases on the ability to take advantage of economic opportunities and cope with risks and, most importantly, for the welfare of the household.

Land reforms in Africa were considered an extraordinary case with its abundance of the land. Still, in recent times, land in Africa is scared due to the high population growth affecting the socio-economic development of the individual and economy. The lack of land markets, however, prevents the emergence of private land rights and security in particular land property and hinders the development of agriculture as a result of avoiding farmers from expanding on their holdings (Amanor, 1999; Holden, Kaarhus, \& Lunduka, 2006). This, however, hinders the improvement for the small-scale farmers since they have inadequate credit facilities and are not able to use their land titling as collateral to expand their holdings. Based on this, it can be said that the increasing population pressure in the country affects the commercialization of the agricultural systems. Land rights have led to a low or decrease in land productivity as a result of lack of infrastructure, low level of technology, and market efficiency (Amanor, 1999).

In the case of Ghana, most women lose their title to land as soon as their husbands die as such their rights to food is taken away from them. The increase of the public discussion on governance and its emphasis on the governance issues with policy deliberations aided with the effect of institutional quality on economic performance (Leite \& Weidmann, 1999; Dellepiane-Avellaneda, 2010). There have been researches on the malfunctioning of government institutions on natural resources, e.g., Shleifer and Vishny (1993); Mehlum, Moene, and Torvik (2006), who debated that most of the developing countries face dysfunction of the government institutions that in turn harm the economic performances through a decrease of both the incentive and opportunities to invest and innovate. Among the difference in governmental policies in developing countries, corruption has received particular publicity, mostly in developing countries by both policymakers and researchers. Government corruption, as examined by Shleifer and Vishny (1993), is the sale by government officials of government properties for personal gain. The customary and legal systems of the coexistence of property rights are a common phenomenon that, in most cases, results in the undervaluation of land in Ghana. This, however, implies that there could be a great benefit of the utilization of these resources for both the customary and legal management systems in Ghana. Potential conflicts of interest may arise due to the overlapping of property rights regimes between different interest groups, such as within the local level and the national level.

Based on the effects of property rights, there can laws put in place to govern and reinforce the rights to the property. Property rights to land in Ghana should uphold laws stating the removal of chemicals such as mercury from the land that could benefit the individuals that own the land. To improve the outcome of natural resource management policies and projects in terms of their efficiency, environmental sustainability, equity, and empowerment of the use of resources, attention must be given to the gender differences in property rights within Africa. Though it may be impossible to generalize across cultures, it is essential to identify the right of the individual, be it, man or woman, to obtain the right to land, water, and other resources.

\subsection{Land Inheritance and Poverty}

Land ownership is a critical asset that provides the people living in the rural and urban areas a means of livelihood through the production and sale of crops that generates income and provides rights for housing for the poor within those communities from the sale of these crops (Meinzen-Dick, Kameri-Mbote, \& Markelova, 2009). Property rights in the developing world are very important in determining the people's right to land and the entitlement to food that helps break the poverty transmission. 
The link between property rights and poverty can go a long way when the government may forcefully take an individual's private property for the development of the economy and, in return, pays the people little or no compensation (Deininger, 2003). This is due to the situation that not only poor people, mostly in Africa, lack basic income, but also these people do not have ownership of assets such as land to be able to generate income. Ghana is predominantly an agricultural country that depends mostly on its earning from cultivated small farmland for agricultural production.

Meinzen-Dick et al. (2009) examines that millions of the urban and the rural poor living in the informal settlement, such as the slams, may lack access to land or their rights to the land which may not be formally or legally recognized by the state. For poverty to reduce in the developing world in the case of Ghana is to readdress this ambiguity through legislation to provide a more secure land tenure system to the poor in these countries. In Africa, the rural and urban poor people understand the concept of land as the most important asset that provides a means of livelihood through farming and sale of land to prospective investors. Meinzen-Dick, R. et al. (2009) further examines the relationship between property rights and poverty reduction as a result of gender equity to land.

\subsubsection{Land Ownership and Transgenerational Equity}

Transgenerational equity may have both positive and negative effects on the distribution and value of resources. Due to the vast increase in the human capital and improvement of utilization of resources, generations focus mainly on the growing production of their capital through the utilization of their natural resources (Gylfason \& Zoega, 2006). Based on this idea, it can be argued that generations have clarity on how to influence market welfare. This can be described as a long-term generational consequences that enables an individual to inherit their natural and social resources through a transfer process. In Ghana, some culture enjoys the benefits and rights to inherits land resources that have been conserved and transferred to the next generation. The Akan tribe from Ghana has enjoyed the inheritance that can be transferred from the deceased man to his brother or nephew. Furthermore, it argues that the Akan tribe allows sons to inherit land from their matrilineal relatives. They conclude by stating that recently the Akan tribe also allows inheritance from husband to wife and children as a form of gifts.

\subsubsection{Litigation and Conflicts as a Result of Land Ownership}

Land conflicts are a widespread phenomenon and occur frequently. Need, greed, scarcity, and the increase in land value are the common causes of land disputes (Wehrmann, 2008). According to Loode, Nolan, Brown, and Clements (2009), land disputes types are:

$>$ Land administration: This occurs between customary landowners and the government. This involves the transfer of land without no records or tangible evidence.

$>$ Land tenure disputes: Use and denial of use of any communally owned land to either individual, rivalries over membership, or influence in land-owning groups. Disagreements as a result of the use of village land or townland by communities. This dispute also involves conflicts such as the use of village or townland by communities due to customary inheritance laws.

$>$ Disputes over land boundaries: Arises as a result of community members seeking to fulfil their needs for more exclusive demarcation of land.

The authors (Loode et al., 2009) further state that conflict resolution processes exist to ensure. The processes can be: customary (traditionally based and can be held anytime without costs being incurred or any delays, for instance using third parties such as chiefs, elders or witnesses); introduced processes (land commissions, land registration, and recording, land boards, ordinary courts, land tribunals, and land courts).

In addition, Immanuel (2010) further reiterates that major reforms have been done to address these disputes. For instance, restitution, redistribution, inheritance, independent ownership, co-ownership, registration of family or clan land and joint titling are among the other actions that have been undertaken in various countries to curb land conflicts.

In Ghana, land disputes, litigations, and other related problems came about due to the lack of written data or records on land ownership (Kasanga \& Kotey, 2001). Ghana has several informal land markets that lead to disputes as a result of a lack of documentation. This results form about $80 \%$ of the land system ownership that is held by the customary landowners, family heads, and traditional authorities.

\section{Materials and Methods}

The paper seeks to focus on property rights and its effect on agricultural production in Ghana. The purpose of this paper is to achieve quantitative research which was applied with attention to the questionnaire survey as a 
method of data collection in Ghana. The questionnaires were administered online, and some to randomly selected individuals. Such surveys are the main sources of information to set strategies aimed at meeting needs or understanding of perceptions, most importantly showing relationships and possible areas of improvement (Munari, Ielasi, \& Bajetta, 2013).

This study targeted a total of 50 respondents at random who are residing in urban and rural areas in Ghana. However, due to limitations such as unwillingness to provide more information on unclear answers and some people asking for money to participate in the interviews, this research only yielded a total of 35 respondents, as shown in the results chapter. Also, the data set was screened for code violations and missing data, using SPSS descriptive statistics and visual inspection by the researcher.

Furthermore, the following assumptions were set for this research based on extensive literature review:

Interviews checklist was based on opinions from experts and findings from past researches. The paper sort to examine 50 respondents who are residing in urban and rural areas in Ghana. However, due to the limited number of respondents willing to provide information during the interview regarding their properties, the research only yielded a total of 35 respondents, as shown in the results chapter. Furthermore, the following assumptions were set for this research based on extensive literature review:

The assumptions were set for this research:

SA1: Men inherit more property than women.

SA2: Family ownership is the most popular type of land ownership in Ghana

SA3: Education level is a key determinant of land inheritance and ownership.

SA4: Patrilineal system of inheritance is practiced more in Ghana than the matrilineal system.

Software SPSS 22.0 and descriptive statistics are employed to analyse data. The significance level used is 0.05 . Moreover, Pearson's chi-square test is used to test the assumptions as indicated above.

$$
\begin{aligned}
& x^{2}=\sum_{i=1}^{r} \frac{\left(n i j-n i^{\circ} j\right)^{2}}{n i^{\circ} j} \\
& x^{2}=\sum_{j=1}^{s} \frac{\left(n i j-n i^{\circ} j\right)^{2}}{n i^{\circ} j}
\end{aligned}
$$

Equations 1 and 2 depict the investigation of homogeneity of the mentioned values that are associated to a particular class (column or row).

$$
x^{2}=\sum_{i=1}^{r} \sum_{j=1}^{s}\left(n i j-n i^{\circ} j\right)^{2}
$$

Equation 3 indicates the minimisation of the variance that has been obtained between model and observation.

Equation 4 shows the minimization of the $\mathrm{X}^{2}$ statistic.

$$
x^{2}=\sum_{i=1}^{r} \sum_{j=1}^{S} \frac{\left(n i j-n i^{\circ} j\right)^{2}}{n i^{\circ} j}
$$

Where, $x^{2}=$ Test statistic of a $\chi^{2}$ distribution; $n i j=$ Observed cell count/frequency of the ith class; $n i^{\circ} j=$ Expected cell count/frequency of the ith class.

$$
f l i=a_{0}+m l i+s i_{p}+s i_{m}+e d u s u+t f a m_{c}+\text { tfam }_{i}+\text { tfam }_{s}+e
$$

Where, $f l i$ is female land inheritance, $m l i$ is male land inheritance, $s i$ is system of inheritance $\left(s i_{p}=\right.$ patrilineal system and $s i_{m}=$ matrilineal system), edusu is educational level of successor and tfam is type of family ownership $\left(\right.$ tfam $_{c}=$ customary, tfam $_{i}=$ individual and tfam $_{s}=$ state) and $e$ is error component.

\section{Results}

The respondents were categorized into two categories as depicted in Tables 1.

Table 1. Gender distribution of land inheritance

\begin{tabular}{lcc}
\hline Gender & Frequency & Percent \\
\hline Male & 22 & 62.86 \\
Female & 13 & 37.14 \\
\hline Total & $\mathbf{3 5}$ & $\mathbf{1 0 0 . 0}$ \\
\hline
\end{tabular}

Source: Author, 2019. 
Table 1 shows that majority $62.86 \%$ of the respondents were males while $37.14 \%$ were female. On the other hand, figure 1 shows the respondents data based on the tribes in Ghana and categorized according to gender attribute. More Ga women (30.7\%) inherit land more than men (22.7\%). According to the results, less Ewe men (13.6\%) inherit land in Ghana.

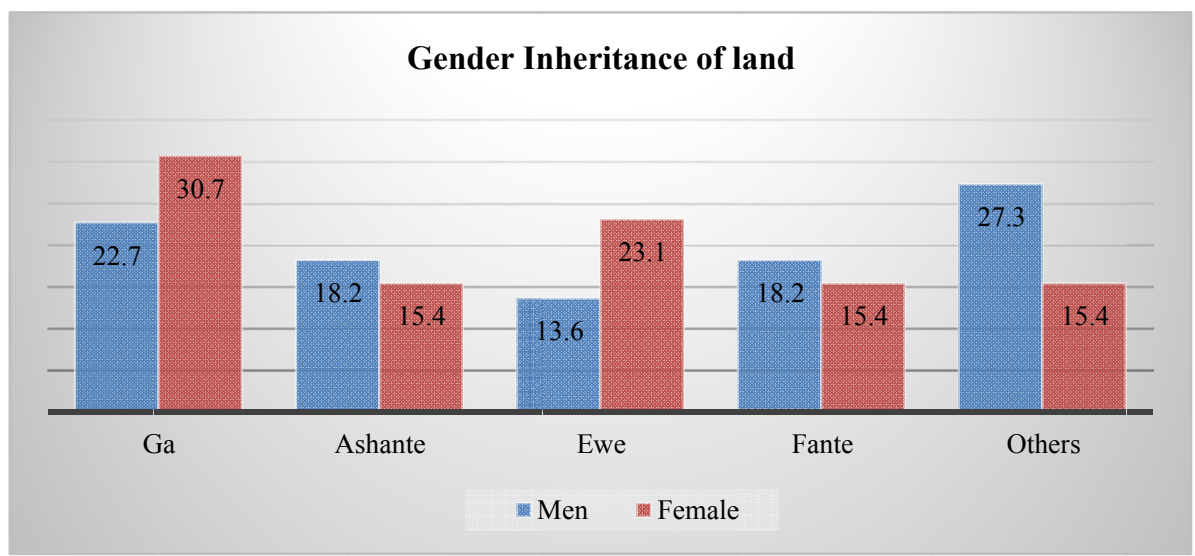

Figure 1. Gender distribution of land Inheritance by Tribe

Source: Author, 2019.

Table 2. Land inheritance according to age

\begin{tabular}{|c|c|c|c|c|c|c|c|c|}
\hline \multirow{2}{*}{ Have you inherited any property? } & \multirow{2}{*}{ In total } & \multicolumn{2}{|c|}{ Gender } & \multicolumn{3}{|c|}{ Age } & \multicolumn{2}{|c|}{ Education level } \\
\hline & & Men & Women & Under 30 & $30-50$ & Over 50 & Higher & Lower \\
\hline Yes in $\%$ & 64 & 68 & 59 & 20 & 64 & 64 & 56 & 64 \\
\hline No in $\%$ & 33 & 22 & 39 & 80 & 33 & 32 & 40 & 36 \\
\hline Did not answer \% & 3 & 10 & 2 & 0 & 3 & 4 & 4 & 0 \\
\hline Critical values of $\chi^{2}$ & & 5.99 & & 9.49 & & & 5.99 & \\
\hline Calculated values of $\chi^{2}$ & & 5.86 & & 5.33 & & & 4.99 & \\
\hline
\end{tabular}

Source: Author, 2019.

In Ghana, 64\% of respondents have inherited a property. Men (68\%) inherited more than women (59\%). Respondents aged between 30-50 and those aged above 50 years have inherited more than age group under 30 years. No significant differences in overall inheritance as to regards to the educational level.

Tables 3 and 4 indicate types of land ownership and inheritance types in Ghana, based on attributes: gender, age, and level of education.

Table 3. Type of land ownership

\begin{tabular}{|c|c|c|c|c|c|c|c|c|c|}
\hline \multirow{2}{*}{\multicolumn{2}{|c|}{$\begin{array}{l}\text { Please state the type of land ownership } \\
\text { (you can list up to three reasons) }\end{array}$}} & \multirow{2}{*}{ In total } & \multicolumn{2}{|c|}{$\operatorname{Gender}\left(\chi^{2}=3.84 *\right)$} & \multicolumn{3}{|c|}{ Age $\left(\chi^{2}=5.99 *\right)$} & \multicolumn{2}{|c|}{ Education level $\left(\chi^{2}=3.84 *\right)$} \\
\hline & & & Men & Women & Under 30 & $30-50$ & Over 50 & Higher & Lower \\
\hline \multirow[b]{2}{*}{ Government } & $\%$ & \multirow[t]{2}{*}{14} & 16 & \multirow[t]{2}{*}{13} & 12 & \multirow[t]{2}{*}{12} & \multirow[t]{2}{*}{22} & 14 & \multirow[t]{2}{*}{14} \\
\hline & $x^{2}$ & & 0.50 & & 4.26 & & & 0.00 & \\
\hline \multirow{2}{*}{ Rented } & $\%$ & \multirow[t]{2}{*}{18} & 21 & \multirow[t]{2}{*}{16} & 13 & \multirow[t]{2}{*}{20} & \multirow[t]{2}{*}{21} & 21 & \multirow[t]{2}{*}{15} \\
\hline & $x^{2}$ & & 1.21 & & 4.26 & & & 1.96 & \\
\hline \multirow{2}{*}{ Private Ownership } & $\%$ & \multirow[t]{2}{*}{50} & 45 & \multirow[t]{2}{*}{52} & 44 & \multirow[t]{2}{*}{52} & \multirow[t]{2}{*}{53} & 38 & \multirow[t]{2}{*}{56} \\
\hline & $\chi^{2}$ & & 1.86 & & 1.81 & & & 10.27 & \\
\hline \multirow{2}{*}{ Family ownership } & $\%$ & \multirow[t]{2}{*}{75} & 68 & \multirow[t]{2}{*}{79} & 89 & \multirow[t]{2}{*}{74} & \multirow[t]{2}{*}{50} & 69 & \multirow[t]{2}{*}{83} \\
\hline & $\chi^{2}$ & & 4.79 & & 30.04 & & & 8.02 & \\
\hline \multirow{2}{*}{ Other (please specify) } & $\%$ & \multirow[t]{2}{*}{17} & 10 & \multirow[t]{2}{*}{21} & 17 & \multirow[t]{2}{*}{13} & \multirow[t]{2}{*}{28} & 17 & \multirow[t]{2}{*}{17} \\
\hline & $\chi^{2}$ & & 6.92 & & 6.59 & & & 0.03 & \\
\hline
\end{tabular}

Note. ${ }^{*}$ Critical values of $\chi^{2}$.

Source: Author, 2019. 
Family ownership (75\%) is the main type of land ownership in Ghana. The option was statistically preferred by respondents under the age of 30 and those with higher education. Respondents with lower education (56\%) statistically acknowledged private ownership as their type of land ownership compared to those with higher education (38\%). Those over age 50 have properties through private ownership (53\%). Other types of land ownership (e.g. customary freehold) statistically influence ownership based on gender and age. Government ownership is the least type of land ownership.

Table 4. Type of inheritance

\begin{tabular}{|c|c|c|c|c|c|c|c|c|}
\hline \multirow{2}{*}{ Type of inheritance system } & \multirow{2}{*}{ In total } & \multicolumn{2}{|c|}{ Gender } & \multicolumn{3}{|c|}{ Age } & \multicolumn{2}{|c|}{ Education level } \\
\hline & & Men & Women & Under 30 & $30-50$ & Over 50 & Higher & Lower \\
\hline Patrilineal in \% & 62 & 66 & 55 & 65 & 60 & 66 & 60 & 66 \\
\hline Matrilineal in \% & 26 & 23 & 31 & 25 & 29 & 22 & 26 & 27 \\
\hline Did not answer in \% & 12 & 11 & 14 & 10 & 11 & 12 & 14 & 7 \\
\hline Critical values of $\chi^{2}$ & & 5.99 & & 9.49 & & & 5.99 & \\
\hline Calculated values of $\chi^{2}$ & & 3.89 & & 1.32 & & & 4.50 & \\
\hline
\end{tabular}

Source: Author, 2019.

In Ghana, $62 \%$ of land inheritance is acquired through a patrilineal system. In terms of gender, more men (66\%) have acquired land as a result of the patrilineal system than women (55\%). Those with lower education have more patrilineal inheritance than those with higher education.

Regression of acres of land: female land inheritance: male land inheritance: patrilineal system: matrilineal system: education and type of family ownership (customary, individual, and state).

Table 5. Effects of multiple regression

\begin{tabular}{ll}
\hline Dependent variable: Acres of land & \\
\hline Independent variable & Model \\
\hline Female land inheritance & $0.124^{* *}(0.040)$ \\
Male land inheritance & $0.201^{* *}(0.020)$ \\
Patrilineal System & $-0.011^{* * *}(0.001)$ \\
Education $($ edusu $)$ & $0.142^{* *}(0.050)$ \\
Type of land ownership-Customary $\left(\right.$ tfam $\left._{c}\right)$ & $0.144^{* *}(0.060)$ \\
Type of land ownership-Individual $\left(\right.$ tfam $\left._{i}\right)$ & $0.175^{*}(0.010)$ \\
No. of observations & 35 \\
R-squared & 0.7900 \\
Adj. R-squared & 0.7465 \\
Prob $>$ F & 0.0000 \\
\hline
\end{tabular}

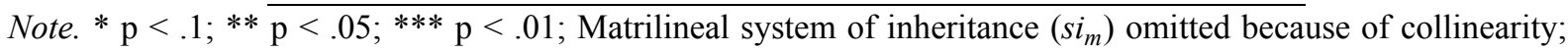
Type of family ownership $\left(\mathrm{tfam}_{s}\right)$ by state omitted because of collinearity.

Source: Author, 2019.

The results show an R-squared of 79 percent, which means that about 79 percent of the variations in agricultural production (proxy by acres of land) is explained by the independent variables considered. The results show a positive effect of the variable, land inherited by females on agricultural production. This can mean that the more females inherit the land, the likelihood there is an increase in agricultural production. As represented in Table 5 above, education has a significant effect on agricultural production. This means that the more people who inherit land are educated, the higher the increase in agricultural production. Also, the practice of customary land ownership has a significant effect on agricultural production as compared to individual ownership system. Finally, it is observed in the results that male land inheritance has a negative effect on agricultural production. This is so because most of the men that inherit land is some communities mostly practice fishing rather than farming.

\section{Discussion}

Based on the sample from 35 respondents ( $62.86 \%$ were male and of $37.14 \%$ were female), this research found that $64 \%$ of Ghanaians have inherited the land. Furthermore, the results showed that men (68\%) had inherited more 
than women (59\%). The results further indicated that Ghanaians agents 30 years and above inherit more than the lower age groups. Therefore, scientific assumption 1 (men inherit more property than women) had confirmed. This result is further reinforcing research work by FAO (2019) who quote from Doss et al. (2011) that property owner as of 2010 in Ghana for females was $38 \%$ and $62 \%$ by males. Also, Whitehead and Tsikata (2003) explain that women's rights to property ownership are limited, thus increase voice for statutory reforms to secure more property ownership rights for women. This was also evident from the result of the multiple regression analysis that shows a positive effect of female land inheritance on agricultural production. This means that advocating for female land inheritance is crucial to increase agricultural production.

Different type of land ownerships exists in Ghana. They include private, family, government, and rented. The analysis showed that family ownership (75\%) is a popular form of land ownership in Ghana. This was statistically preferred by respondents below the age of 30 years and those with a lower level of education. In addition, people with lower education (83\%) are more prone to own family land than people with higher education $(69 \%)$. Private ownership (50\%) is the second most popular form of land ownership, followed by rented (18\%) and then government ownership (17\%). The respondents also outlined other types of land inheritance (17\%), such as customary freehold. The research results are in agreement with Deininger (2003), who states that in Ghana land ownership is family-based that is mainly used for agricultural activities. Furthermore, the patrilineal system (62\%) is the most popular form of land inheritance in Ghana than Matrilineal $(26 \%)$. Of the respondents, $12 \%$ opted not to answer the question regarding the type of inheritance system. Besides, the patrilineal system was favored more by respondents with lower education.

The above test results have therefore confirmed assumptions 2 (family ownership is the most popular type of land ownership in Ghana), 3 (education level is a crucial determinant of land inheritance and ownership), and 4 (patrilineal system of inheritance is practiced more in Ghana than matrilineal system).

As quoted by Eliana La Ferrara et al. (2014), property rights can be made more secure with the inheritance of resources from the father or uncle in a family to the male child. It can be argued that even though fathers may have ownership of land right when it comes to the matrilineal norms in the Ghanaian society, it is believed that the uncles from the maternal side have no control of the land and thus gives more importance to educating the child. As such, in order to strengthen the poor people's control over the assets can be through multiple sources on poverty interventions.

\section{Conclusion}

This paper investigated the property rights and its effect on natural resources in Ghana through the use of a questionnaire survey as a method of data collection and based on the recommendations from (Munari, Ielasi \& Bajetta, 2013). A total of 35 respondents were valid for this paper. Data from the questionnaires were analyzed using SPSS 22.0 software.

The findings indicate that men have the upper hand when it comes to inheritance, and they usually inherit more than women. However, the multiple regression results showed a positive effect of female land inheritance on agricultural production, which means support should be given to the advocacy of more female land inheritance in Ghana. Family ownership is the popular form of land ownership in Ghana; education level determines land inheritance and ownership, and the patrilineal system is widely practiced in Ghana as a system of inheritance.

Furthermore, the findings of this study have important implications for scientific research. The paper enriches the already available literature by providing more current literature on property rights, land ownership, and land inheritance in Ghana. To policymakers, it is essential for them to strengthen laws that protect land inheritance and ownership for women as it was evident that men are more prone to inherit than women. In addition, female land inheritance was found to have a highly positive significant effect on the increase in agricultural production.

Future research should focus on ways and policies that can be implemented to ensure equal rights of land inheritance and ownership in the society irrespective of age, gender, and education.

\section{References}

Adger, W. N., \& Luttrell, C. (2000). Property rights and the utilisation of wetlands. Ecological Economics, 35(1), 75-89. https://doi.org/10.1016/S0921-8009(00)00169-5

Alchian, A. A. (1989). Property rights. The Invisible Hand (pp. 232-238). Palgrave Macmillan, London. https://doi.org/10.1007/978-1-349-20313-0_31

Amacher, G. S., \& Malik, A. S. (1996). Bargaining in environmental regulation and the ideal regulator. Journal of Environmental Economics and Management, 30(2), 233-253. https://doi.org/10.1006/jeem.1996.0016 
Aryeetey, E., \& Udry, C. (2010). Creating property rights: Land banks in Ghana. American Economic Review, 100(2), 130-34. https://doi.org/10.1257/aer.100.2.130

Becker, L. C. (2014). Property Rights (Routledge Revivals): Philosophic Foundations. Routledge.

Blocher, J. (2006). Building on custom: land tenure policy and economic development in Ghana. Yale Hum. Rts. \& Dev., 9, 166.

Deere, C. D., Oduro, A. D., Swaminathan, H., \& Doss, C. (2013). Property rights and the gender distribution of wealth in Ecuador, Ghana and India. The Journal of Economic Inequality, 11(2), 249-265. https://doi.org/ $10.1007 / \mathrm{s} 10888-013-9241-\mathrm{Z}$

Deininger, K. W. (2003). Land policies for growth and poverty reduction. World Bank Publications.

Dellepiane-Avellaneda, S. (2010). Good governance, institutions and economic development: Beyond the conventional wisdom. British Journal of Political Science, 40(1), 195-224. https://oi.org/10.1017/ S0007123409990287

Doss, C., Deere, C. D., Oduro, A. D., Swaminathan, H., Suchitra, J. Y., Lahoti, R., \& Catanzarite, Z. (2011). The gender asset and wealth gaps: Evidence from Ecuador, Ghana, and Karnataka, India. Bangalore: Indian Institute of Management Bangalore.

Gylfason, T., \& Zoega, G. (2006). Natural resources and economic growth: The role of investment. World Economy, 29(8), 1091-1115. https://doi.org/10.1111/j.1467-9701.2006.00807.x

Heltberg, R. (2002). Property rights and natural resource management in developing countries. Journal of Economic Surveys, 16(2), 189-214. https://doi.org/10.1111/1467-6419.00164

Hilson, G. (2002). An overview of land use conflicts in mining communities. Land Use Policy, 19(1), 65-73. https://doi.org/10.1016/S0264-8377(01)00043-6

Hilson, G., \& Yakovleva, N. (2007). Strained relations: A critical analysis of the mining conflict in Prestea, Ghana. Political Geography, 26(1), 98-119. https://doi.org/10.1016/j.polgeo.2006.09.001

Holden, S., Kaarhus, R., \& Lunduka, R. (2006). Land policy reform: The role of land markets and women's land rights in Malawi. Noragric.

Ikdahl, I., Hellum, A., Kaarhus, R., Benjaminsen, T. A., \& Kameri-Mbote, P. (2005). Human rights, formalisation and women's land rights in southern and eastern Africa. Noragric, Norwegian University of Life Sciences.

Immanuel, K. F. (2010). Challenges and opportunities for women's land rights in post-conflict northern Uganda (MICROCON Research Working Paper 26). https://doi.org/10.2139/ssrn.1650248

Joireman, S. F. (2008). The mystery of capital formation in Sub-Saharan Africa: women, property rights and customary law. World Development, 36(7), 1233-1246. https://doi.org/10.1016/j.worlddev.2007.06.017

Kasanga, R. K., \& Kotey, N. A. (2001). Land management in Ghana: Building on tradition and modernity.

La Ferrara, E., \& Milazzo, A. (2017). Customary norms, inheritance, and human capital: evidence from a reform of the matrilineal system in Ghana. American Economic Journal: Applied Economics, 9(4), 166-85. https://doi.org/10.1257/app.20150342

Lastarria-Cornhiel, S. (1997). Impact of privatization on gender and property rights in Africa. World Development, 25(8), 1317-1333. https://doi.org/10.1016/S0305-750X(97)00030-2

Leite, C. A., \& Weidmann, J. (1999). Does mother nature corrupt: Natural resources, corruption, and economic growth (IMF Working Paper No. 99/85). International Monetary Fund. https://doi.org/10.5089/978145185 0734.001

Loode, S., Nolan, A., Brown, A., \& Clements, K. (2009). Conflict management processes for land-related conflict. Pacific Islands Forum Secretariat, Fiji.

May, C. (2015). The global political economy of intellectual property rights: The new enclosures. Routledge. https://doi.org/10.4324/9780203873816

Mehlum, H., Moene, K., \& Torvik, R. (2006). Institutions and the resource curse. The Economic Journal, 116(508), 1-20. https://doi.org/10.1111/j.1468-0297.2006.01045.x

Meinzen-Dick, R. S., Brown, L. R., Feldstein, H. S., \& Quisumbing, A. R. (1997). Gender, property rights, and natural resources. World Development, 25(8), 1303-1315. https://doi.org/10.1016/S0305-750X(97)00027-2 
Meinzen-Dick, R., \& Mwangi, E. (2009). Cutting the web of interests: Pitfalls of formalizing property rights. Land Use Policy, 26(1), 36-43. https://doi.org/10.1016/j.landusepol.2007.06.003

Meinzen-Dick, R., Kameri-Mbote, P., \& Markelova, H. (2009). Property rights for poverty reduction? New York, USA.

Merrill, T. W., \& Smith, H. E. (2001). What happened to property in law and economics. The Yale Law Journal, 111(2), 357-398. https://doi.org/10.2307/797592

Munari, L., Ielasi, F., \& Bajetta, L. (2013). Customer satisfaction management in Italian banks. Qualitative Research in Financial Markets, 5(2), 139-160. https://doi.org/10.1108/QRFM-11-2011-0028

Nyame, F. K., \& Blocher, J. (2010). Influence of land tenure practices on artisanal mining activity in Ghana. Resources Policy, 35(1), 47-53. https://doi.org/10.1016/j.resourpol.2009.11.001

Ostrom, E. (2009). Design principles of robust property-rights institutions: What have we learned? In K. G. Ingram, \& H. Yu-Hung (Eds.), Property Rights and Land Policies Cambridge, MA: Lincoln Institute of Land Policy.

Peters, P. E. (2013). Conflicts over land and threats to customary tenure in Africa. African Affairs, 112(449), 543-562. https://doi.org/10.1093/afraf/adt047

Quisumbing, A. R., Payongayong, E. M., \& Otsuka, K. (2004). Are Wealth Transfers Biased Against Girls? Gender Differences in Land Inheritance and Schooling Investment in Ghana's Western Region (No. 583-2016-39691).

Quisumbing, M. A. R. (2001). Land, trees, and women: Evolution of land tenure institutions in Western Ghana and Sumatra (Vol. 121). Intl. Food Policy Res. Inst.

Schlager, E., \& Ostrom, E. (1992). Property-rights regimes and natural resources: A conceptual analysis. Land Economics, 249-262. https://doi.org/10.2307/3146375

Shandro, J. A., Veiga, M. M., \& Chouinard, R. (2009). Reducing mercury pollution from artisanal gold mining in Munhena, Mozambique. Journal of Cleaner Production, 17(5), 525-532. https://doi.org/10.1016/j.jclepro. 2008.09.005

Shleifer, A., \& Vishny, R. W. (1993). Corruption. The Quarterly Journal of Economics, 108(3), 599-617. https://doi.org/10.2307/2118402

Ubink, J. M., \& Quan, J. F. (2008). How to combine tradition and modernity? Regulating customary land management in Ghana. Land Use Policy, 25(2), 198-213. https://doi.org/10.1016/j.landusepol.2007.06.002

Wehrmann, B. (2008). Land conflicts: A practical guide to dealing with land disputes. Eschborn: GTZ.

Whitehead, A., \& Tsikata, D. (2003). Policy discourses on women's land rights in Sub-Saharan Africa: The implications of the return to the Customary. Journal of Agrarian Change, 3(1-2), 67-112. https://doi.org/10.1111/1471-0366.00051

Whittal, J. (2014). A new conceptual model for the continuum of land rights. South African Journal of Geomatics, $3(1), 13-32$.

\section{Internet References}

The Role of Property Rights in Natural Resource Management, Good Governance and Empowerment of the Rural Poor. Retrieved September 10, 2019, from https://www.usaidlandtenure.net/wp-content/uploads/2016/ 09/USAID_Land_Tenure_Property_Rights_and_NRM_Report.pdf

Distribution of Agricultural Landowners by Sexes (Females). Retrieved September 10, 2019, from http://www.fao.org/gender-landrights-database/data-map/statistics/en/?sta_id=1162 


\section{Appendix A}

Summary Statistics of acres of land: female land inheritance: male land inheritance: patrilineal system: matrilineal system: education and type of family ownership (customary, individual and state)

\begin{tabular}{llllll}
\hline Variables & Obs & Mean & Standard Deviation & Minimum & Maximum \\
\hline Acres of land & 35 & 3.885714 & 2.323428 & 1 & 10 \\
Female land inheritance $($ fli $)$ & 35 & .3714286 & .4902409 & 0 & 1 \\
Male land inheritance $(\mathrm{mli})$ & 35 & .6285714 & .4902409 & 0 & 1 \\
Patrilineal system $\left(s i_{p}\right)$ & 35 & .5714286 & .5020964 & 0 & 1 \\
Matrilineal system $\left(\mathrm{si} i_{m}\right)$ & 35 & .4285714 & .5020964 & 0 & 1 \\
Education $(\mathrm{edusu})$ & 35 & .6 & .4970501 & 0 & 1 \\
Type of land ownership-Customary $\left(\right.$ tfam $\left._{c}\right)$ & 35 & .5714286 & .5020964 & 0 & 1 \\
Type of land ownership-Individual $\left(\right.$ tfam $\left._{i}\right)$ & 35 & .3142857 & .4710082 & 0 & 1 \\
Type of land ownership-State $\left(\right.$ tfam $\left._{s}\right)$ & 35 & .1142857 & .3228029 & 0 & 1 \\
\hline
\end{tabular}

Source: Author, 2019.

\section{Appendix B}

Correlation of acres of land: female land inheritance: male land inheritance: patrilineal system: matrilineal system: education and type of family ownership (customary, individual and state)

\begin{tabular}{|c|c|c|c|c|c|c|c|c|c|}
\hline & Acres of land & $f l i$ & $m l i$ & $s i_{p}$ & $s i_{m}$ & edusu & tfam $_{c}$ & tfam $_{i}$ & tfam $_{s}$ \\
\hline Acres of land & 1.0000 & & & & & & & & \\
\hline$f l i$ & -0.1424 & 1.0000 & & & & & & & \\
\hline$m l i$ & 0.1424 & -1.0000 & 1.0000 & & & & & & \\
\hline$s i_{p}$ & -0.0432 & -0.1707 & 0.1707 & 1.0000 & & & & & \\
\hline$s i_{m}$ & 0.0432 & 0.1707 & -0.1707 & -1.0000 & 1.0000 & & & & \\
\hline edusu & 0.3158 & 0.1448 & -0.1448 & -0.1179 & 0.1179 & 1.0000 & & & \\
\hline $\operatorname{tfam}_{c}$ & -0.0432 & 0.0683 & -0.0683 & -0.2833 & 0.2833 & -0.2357 & 1.0000 & & \\
\hline $\operatorname{tfam}_{i}$ & 0.2219 & -0.1383 & 0.1383 & 0.2132 & -0.2132 & 0.3015 & -0.7817 & 1.0000 & \\
\hline tfam $_{s}$ & -0.2566 & 0.0956 & -0.0956 & 0.1296 & -0.1296 & -0.0733 & -0.4148 & -0.2432 & 1.0000 \\
\hline
\end{tabular}

Note. Obs $=35$.

Source: Author, 2019.

\section{Copyrights}

Copyright for this article is retained by the author(s), with first publication rights granted to the journal.

This is an open-access article distributed under the terms and conditions of the Creative Commons Attribution license (http://creativecommons.org/licenses/by/4.0/). 